
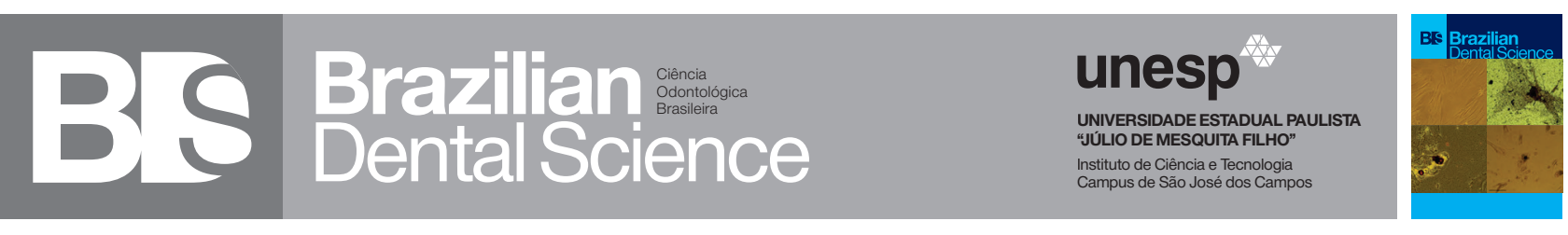

\title{
Prevalence of temporomandibular disorder and its association with stress and anxiety among university students
}

\author{
Prevalência de Disfunção Temporomandibular e sua associação com Estresse e Ansiedade entre Universitários \\ Larissa Aparecida Benincá TON ${ }^{1}$, Iago Gomes MOTA ${ }^{1}$, Janice Simpson DE PAULA ${ }^{2,3}$, Ana Paula Varela Brown MARTINS ${ }^{1,2}$ \\ 1 - Department of Dentistry - Federal University of Juiz de Fora - Governador Valadares - MG - Brazil. \\ 2 - School of Dentistry of Piracicaba - State University of Campinas - Piracicaba - SP - Brazil. \\ 3 - Department of Social and Preventive Dentistry - Federal University of Minas Gerais - Belo Horizonte - MG - Brazil.
}

\section{ABSTRACT}

Objective: The objective was to evaluate the prevalence of Temporomandibular Disorders (TMD) and the association with stress and anxiety among university students. Material and Methods: The Fonseca Anamnestic Index, Trait-State Anxiety Inventory (IDATE) and LIPP Stress Symptom Inventory (LIPP) were applied for 714 voluntaries. Descriptive and inferential statistical analyzes were performed using the chi-square or Fisher's exact test and the Student's t-test or ANOVA, significance level of $5 \%$. Results: The prevalence of TMD was $68.63 \%$, $46.9 \%$ had mild TMD. There was a statistically significant difference between the means of age and the severity of the TMD, higher mean values for severe TMD (22.5 \pm 3.3 years). There was a statistically significant association between the female and TMD, higher prevalence of mild TMD. Among the volunteers diagnosed with TMD, a significant number were diagnosed without stress, but there was a statistically significant association between those diagnosed with stress and mild TMD, anxiety and TMD, (state: moderate anxiety and DTM - 50\%; trait: moderate and severe anxiety and mild DTM $49.3 \%$ and $49.87 \%$, respectively). Conclusion: There was a high prevalence of TMD signs and symptoms, with higher prevalence in the female gender, mild TMD was more significant, and anxiety and stress were significantly present among university students with TMD signs and symptoms.

\section{KEYWORDS}

Temporomandibular disorder; Anxiety; Psychological stress.

\section{RESUMO}

Objetivos: A disfunção temporomandibular (DTM) consiste em uma desordem multifatorial, que envolve a articulação temporomandibular, os músculos mastigatórios e estruturas associadas. Fatores psicológicos como estresse e ansiedade estão associados com seu desenvolvimento. Alunos universitários, em virtude de apresentar a faixa etária de maior prevalência e estaremsob estresse e/ou ansiedade, despertam interesse para estudos daDTM. O objetivo foi avaliar a prevalência de DTM e a associação com estresse e ansiedade entre os universitários. Material e Métodos: foram entrevistados 714 estudantes de todos os cursos de uma universidade, de ambos os gêneros. Foram aplicados o Índice Anamnésico de Fonseca, Inventário de Ansiedade Traço-Estado (IDATE) e Inventário de Sintomas de Estresse de LIPP (LIPP). Foram realizadas análises estatísticas descritivas e inferenciais, com uso do teste Qui-quadrado ou exato de Fisher e do teste t-Student ou ANOVA, de acordo com a indicação, com nível de significância de 5\%. Resultados: De acordo com os dados obtidos, a prevalência de DTM entre universitários foi de 68,63\%, sendo que 46,9\% apresentaram DTM leve. Houve diferença estatisticamente significativa entre as médias de idade e a severidade da DTM, de modo que se evidenciou maiores médias na DTM severa (22,5 $\pm 3,3$ anos). Quanto ao gênero, os dados registraram associação estatisticamente significante ( $\mathrm{p}<$ 0,05 ) entre o feminino e DTM, com maior prevalência da DTM leve. Com relação ao perfil psicológico dos voluntários diagnosticados com DTM, um número significativo foi diagnosticado sem estresse, porém houve associação estatisticamente significativa entre aqueles diagnosticados com estresse e DTM LEVE, ansiedade e DTM ( $\mathrm{p}<$ 0,05), (estado: ansiedade MODERADA e DTM LEVE (50\%), e traço: ansiedade MODERADA E SEVERA e DTM LEVE (49,3 \% e 49,87\%, respectivamente). Conclusões: concluiu-se que existe uma elevada prevalência dos sinais e sintomas de DTM entre os universitários, com maior prevalência no gênero feminino, severidade de DTM mais significante foi a leve e a ansiedade e o estresse estiveram significantemente presente entre os portadores dos sinais e sintomas de DTM.

\section{PALAVRAS-CHAVE}

Transtornos da articulação temporomandibular; Ansiedade; Estresse psicológico. 


\section{INTRODUCTION}

T emporomandibular Disorder (TMD) is identified as the major cause of pain, of nondental origin, in the orofacial region [1] and is the second cause of seeking treatment, only behind dental pain [1]. It is defined as a group of musculoskeletal and neuromuscular conditions involving the temporomandibular joints (TMJ), masticatory muscles and all associated tissues [2].

TMDs present common signs and symptoms. Pain is the most frequent symptom and may be localized in the masticatory muscles, the TMJ and/or the preauricular region [1]. Limitation or deviation of the mandibular opening and joint noises are also complaints frequently reported by patients with TMD [1].

The prevalence of TMD varies considerably amongstudies [3], especiallyin themethodological diversity and individual factors selected in each study [4]. Many studies point to the high prevalence of TMD in the various populations studied, such as Sweden, Italy and Brazil [5,6]. In a study conducted in the interior of the state of São Paulo (Ribeirão Preto, SP, Brazil), it was found that nearly $40 \%$ of the population studied had at least one TMD symptom [7]. Even with all the diversity, the studies converge on the female gender as the prevalent distribution, especially in the age range of 18 to 45 years $[5,6,7]$.

Psychosocial factors such as stress, anxiety and depression may contribute to the progression and exacerbation of painful TMD symptomatology [8]. Today, it is known that stress is capable of profoundly affecting the biological processes of transmission and perception of pain [9]. According to Stallman [10], the student population lives under more stress than the general population and, therefore, develops considerably more TMD and parafunctional oral habits.

Even having this information, new epidemiological studies need to be conducted because of the diversity of results and regional differences [7]. The purpose of this study was to estimate the prevalence of TMD and its association with anxiety and stress, among university students in different academic programs and terms, due to its peculiar distribution in the age group and capacity to negatively affect quality of life.

\section{MATERIAL AND METHODS}

This is a cross-sectional, observational, epidemiological study, approved by the Ethics Committee (no. 1.878.567), conducted during the period from January 9 to February 3, 2017. The procedures were in accordance with the Helsinki Declaration of 1975 , as revised in 2000 (available at http://www.wma.net/e/policy/17c_e.html).

\section{Description and Sample}

714 students of both genders (482 women and 232 men), from a total of 2,113 students, were randomly selected to participate in the study. The students were regularly enrolled in various undergraduate programs at Juiz de Fora Federal University, Governador Valadares campus (UFJFGV), with ages ranging from 18 to 60 years. In order to participate in the survey, volunteers must be of legal age (over 18), able to answer questions, and regularly enrolled in one of the UFJF-GV programs. The exclusion criteria adopted were: systemic diseases that could confound the results (rheumatoid arthritis, polyarthritis, heart disease, diabetes mellitus), facial trauma, use of medications that can interfere with the results (chronic use of analgesics, anti-inflammatories, antidepressants), refused to participate or incompletely or incorrectly answered the questionnaires. The campus Graduation Manager was contacted to obtain a list of regularly enrolled students, for continuation of the research.

Due to the infrastructures' geographical distribution of university campus, the diversity of academic schedules of the different courses (avoiding the influence of stressful events that generated a short time - 25 days - for the development of this study) and after applying the exclusion criteria, all factors that justify the final total number of 714 volunteers.

\section{Questionnaires}

To the students were given all the information about the research objectives, the questionnaires used and the procedures performed so that there would be no doubts, especially regarding the confidentiality of 
the information. All were informed about the possibility of discontinuing participation in the study at any time. After everything was explained, those who chose to participate in the study read and signed the informed consent form.

Data were collected after the recess period, as it was a period when students were returning from vacations, believing that they were less likely to be influenced by the psychological changes of the academic routine. To obtain the data, in addition to demographic data (age, gender, race, program and semester), three questionnaires were used:

- Fonseca Anamnestic Index (FAI): it is a validity and reliability questionnaire to diagnosis TMD (presence or not) and its severity (mild, moderate and severe) (Campos et al., 2014). This contains 10 objective questions and, to each one, the possible answers "yes", "sometimes" and "no" are given, to which the values " 10 ", " 5 " and " 0 ", respectively, were assigned. In the end, responses were summed and, from the results, the individual is classified according to the reference ranges as "no DTM" (range 0 to 15); "mild disorder" (range 20 to 40); "moderate disorder" (range 45 to 65); and "severe disorder" (range 70 to 100) [11].

- State Trait Anxiety Inventory (STAI): self-administered questionnaire used to assess the different levels of anxiety of the volunteers. It consists of two questionnaires, each containing 20 statements. The first is anxiety-state, and the second is anxiety-trait; responses from 1 to 4 are possible for each statement. The State scale requires participants to describe how they felt at the exact moment, and the answers can be 1 absolutely none; 2 - a little; 3 - some; 4 - a lot. On the Trace scale, the participants should respond how they "usually feel", and the answers could be 1 - almost never; 2 - sometimes; 3 - often; 4 almost always. After the totaling, the final score ranges from 20 (minimum) to 80 (maximum), so that the classification can be determined as: 20 to 40 points (low anxiety level); 41 to 60 points (average anxiety level); 61 to 80 points (high anxiety level) [12].

- LIPP's Inventory of Stress Symptoms (LIPP): used to quantify and qualify physical and psychological symptoms of stress, categorized in phases (alertness, endurance and exhaustion). This questionnaire consists of three tables which contain physical and psychological symptoms of each stage of stress. To respond, volunteers were directed to indicate which of the symptoms they had felt in the last 24 hours, in the last week and in the last month. After responding, the physical symptoms at each of the stages of time were totaled, and the individual was thus classified as to the presence or absence of stress [9].

\section{Data Analysis}

After the data were collected, they were submitted to statistical analysis, in order to obtain results, using the program SPSS 17.0 Statistics Software (SPSS Inc., Chicago, IL, USA). Descriptive statistical analyses were conducted using frequency calculations (absolute and relative), as well as measures of central tendency and of dispersion (mean and standard deviation). As for the inferential statistical analyses, the Chi-square or the Fisher's exact test was used to compare proportions; and the Student's t-test or the ANOVA was a criterion for comparing averages. All analyses used a significance level of 5\%.

\section{RESULTS}

A total of 714 volunteers participated in the study. The demographic characteristics of the students showed that there was a prevalence of females (67.51\%), whites (42.02\%), and single people (94.68\%) (Table 1).

Table 1 - Demographic characteristics of the university students of UFJF-GV

\begin{tabular}{|c|ccc|}
\hline & CATEGORIES & n & \% \\
\hline \multirow{3}{*}{ Gender } & Females & 482 & 67.51 \\
\hline \multirow{4}{*}{ Race } & Males & 232 & 32.49 \\
\hline \multirow{5}{*}{} & Yellow & 21 & 2.94 \\
\hline \multirow{4}{*}{ Marital status } & White & 300 & 42.02 \\
\hline & Brown & 280 & 39.22 \\
\hline & Black & 67 & 9.38 \\
\hline & Notinformed & 46 & 6.44 \\
\hline & Single & 676 & 94.68 \\
\hline & Married & 27 & 3.78 \\
\hline & Divorced & 2 & 0,28 \\
\hline & Not informed & 9 & 1,26 \\
\hline
\end{tabular}


The mean age of the participants was 21.5 years $( \pm 4.53$ ), and $8 \%$ of the participants did not provide that information. The greatest proportion of volunteers, in relation to regularly enrolled students, were in the programs of Dentistry (53.5\%), followed by Law (40.1\%) (Table 2).

Table 2 - Sample proportion according to their representativeness within the strata (course and period) of UFJF-GV students

\begin{tabular}{|cccc|}
\hline & $\begin{array}{c}\text { Participation } \\
\text { on the Study }\end{array}$ & $\begin{array}{c}\text { Total En- } \\
\text { rolled in the } \\
\text { Course }\end{array}$ & $\begin{array}{c}\text { \% of partici- } \\
\text { pation }\end{array}$ \\
\hline Administration & 62 & 201 & 30.8 \\
\hline Accounting Science & 35 & 106 & 33.0 \\
\hline Economic Science & 37 & 176 & 21.0 \\
\hline Law & 155 & 387 & 40.1 \\
\hline Physical Education & 26 & 95 & 27.4 \\
\hline Pharmacy & 60 & 176 & 34.1 \\
\hline Physiotherapy & 57 & 179 & 31.8 \\
\hline Medicine & 105 & 361 & 29.1 \\
\hline Nutrition & 29 & 159 & 18.2 \\
\hline Dentistry & 146 & 273 & 53.5 \\
\hline Not informed & 2 & & \\
\hline
\end{tabular}

It was verified that TMD was present in 490 university students (68.63\%). Among those diagnosed with TMD, there was a greater prevalence of mild TMD in 335 (46.92\%), followed by moderate TMD in 123 (17.23\%), and severe TMD in only 32 students (4.48\%) (Table 3 ).

Table 3 - Prevalence of Temporomandibular Disorder (TMD) among UFJF-GV students

\begin{tabular}{|c|c|c|}
\hline TMD & $\mathbf{N}$ & $\%$ \\
\hline Absence of TMD & 224 & 31.37 \\
\hline Mild TMD & 335 & 46.92 \\
\hline Moderate TMD & 123 & 17.23 \\
\hline Severe TMD & 32 & 4.48 \\
\hline Total & 714 & 100.00 \\
\hline
\end{tabular}

Evaluating the prevalence of stress and anxiety in the students, it was found that $93.14 \%$ of the students presented no stress, while a significant number of students was diagnosed with anxiety $(96.64 \%$ and $93.7 \%$, for state and trait, respectively). For the anxietystate variable, which refers to anxiety within the last 24 hours, $56.30 \%$ of the volunteers presented severe anxiety; and, for the anxietytrait variable, (last 30 days), 55.04\% presented severe anxiety (Table 4).

Table 4 - Prevalence of stress and anxiety (trait and state) among UFJF-GV students

\begin{tabular}{|c|cc|}
\hline VARIABLE & CATEGORIES & $\mathbf{n ( \% )}$ \\
\hline \multirow{2}{*}{ Stress } & Without stress & $665(93.14 \%)$ \\
& With stress & $49(6.86 \%)$ \\
\hline \multirow{3}{*}{ Anxiety - state } & Without anxiety & $24(3.36 \%)$ \\
& Low anxiety level & $112(15.69 \%)$ \\
\hline & Average anxiety level & $176(24.65 \%)$ \\
\hline \multirow{2}{*}{ Anxiety-trait } & High anxiety level & $402(56.30 \%)$ \\
& Without anxiety & $45(6.30 \%)$ \\
& Low anxiety level & $117(16.39 \%)$ \\
\hline & Average anxiety level & $155(21.71 \%)$ \\
\hline & High anxiety level & $393(55.04 \%)$ \\
\hline
\end{tabular}

Evaluating the prevalence of TMD and the different degrees of severity in relation to gender, there was a significant number of women, diagnosed with TMD (76.35\%). A statistically significant difference between the proportions of degrees of severity of TMD and gender $(\mathrm{p}<0.05)$ was found, observed especially in the greater prevalence of mild TMD (50.62\%) for the female gender and the absence of TMD for the male gender (47.41\%) (Table 5). 
Table 5 - Association of the DTM with the demographic aspects and with the characterization of the course and period of the university students of the UFJF-GV

\begin{tabular}{|c|c|c|c|c|c|c|}
\hline & \multicolumn{4}{|c|}{ TEMPOROMANDIBULARDISORDER(TMD) } & & \multirow[b]{2}{*}{ p-value } \\
\hline & Absence & Mild & Moderate & Severe & & \\
\hline GENDER & $n(\%)$ & $n(\%)$ & n(\%) & $n(\%)$ & Total & \\
\hline Female & $114(23.65 \%)$ & $244(50.62 \%)$ & $101(20.95 \%)$ & $23(4.77 \%)$ & 482 & \multirow{2}{*}{$<0.0001^{\star}$} \\
\hline Male & $110(47.41 \%)$ & $91(39.22 \%)$ & $22(9.48 \%)$ & $9(3.88 \%)$ & 232 & \\
\hline AGE Mean (sd') & $21.0(4.2)$ & $21.4(4.5)$ & $22.3(5.3)$ & $22.5(3.3)$ & $21.5(4.5)$ & $0.05^{\star \star}$ \\
\hline COURSE & $n(\%)$ & $n(\%)$ & $n(\%)$ & $n(\%)$ & Total & \\
\hline Administration & $18(29.03 \%)$ & $30(48.39 \%)$ & $12(19.35 \%)$ & $2(3.23 \%)$ & 62 & $0.49^{\star \star \star}$ \\
\hline Accounting Science & $16(45.71 \%)$ & $13(37.14 \%)$ & $3(8.57 \%)$ & $3(8.57 \%)$ & 35 & \\
\hline Economic Science & $16(43.24 \%)$ & $13(35.14 \%)$ & $5(13.51 \%)$ & $3(8.11 \%)$ & 37 & \\
\hline Law & $51(32.90 \%)$ & $67(43.23 \%)$ & $28(18.06 \%)$ & $9(5.81 \%)$ & 155 & \\
\hline Physical Education & $11(42.31 \%)$ & $11(42.31 \%)$ & $4(15.38 \%)$ & $0(0.00 \%)$ & 26 & \\
\hline Pharmacy & $18(30.00 \%)$ & $30(50.00 \%)$ & $10(16.67 \%)$ & $2(3.33 \%)$ & 60 & \\
\hline Physiotherapy & $14(24.56 \%)$ & $26(45.61 \%)$ & $15(26.32 \%)$ & $2(3.51 \%)$ & 57 & \\
\hline Medicine & $37(35.24 \%)$ & $54(51.43 \%)$ & $12(11.43 \%)$ & $2(1.90 \%)$ & 105 & \\
\hline Nutrition & $7(24.14 \%)$ & $14(48.28 \%)$ & $7(24.14 \%)$ & $1(3.45 \%)$ & 29 & \\
\hline Dentistry & $36(24.66 \%)$ & $75(51.37 \%)$ & $27(18.49 \%)$ & $8(5.48 \%)$ & 146 & \\
\hline Not informed & $00.00 \%)$ & $2(100.00 \%)$ & $0(0.00 \%)$ & $0(0.00 \%)$ & 2 & \\
\hline SEMESTER & $n(\%)$ & $n(\%)$ & $n(\%)$ & $n(\%)$ & & \\
\hline 1 & 64 (38.55\%) & $77(46.39 \%)$ & $19(11.45 \%)$ & $6(3.61 \%)$ & 166 & $0.00^{\star \star \star}$ \\
\hline 2 & $47(40.52 \%)$ & $45(38.79 \%)$ & $20(17.24 \%)$ & $4(3.45 \%)$ & 116 & \\
\hline 3 & $15(20.83 \%)$ & $30(41.67 \%)$ & $20(27.78 \%)$ & $7(9.72 \%)$ & 72 & \\
\hline 4 & $26(33.33 \%)$ & $41(52.56 \%)$ & $9(11.54 \%)$ & $2(2.56 \%)$ & 78 & \\
\hline 5 & $5(17.86 \%)$ & $10(35.71 \%)$ & $9(32.14 \%)$ & $4(14.29 \%)$ & 28 & \\
\hline 6 & $22(28.21 \%)$ & $39(50.00 \%)$ & $15(19.23 \%)$ & $2(2.56 \%)$ & 78 & \\
\hline 7 & $15(25.00 \%)$ & $36(60.00 \%)$ & $8(13.33 \%)$ & $1(1.67 \%)$ & 60 & \\
\hline 8 & $12(32.43 \%)$ & $19(51.35 \%)$ & $5(13.51 \%)$ & $1(2.70 \%)$ & 37 & \\
\hline 9 & $7(16.28 \%)$ & $21(48.84 \%)$ & $11(25.58 \%)$ & $4(9.30 \%)$ & 43 & \\
\hline ni & $11(30.56 \%)$ & $17(47.22 \%)$ & $7(19.44 \%)$ & $1(2.78 \%)$ & 36 & \\
\hline Grand Total & $224(31.37 \%)$ & $335(46.92 \%)$ & $123(17.23 \%)$ & $32(4.48 \%)$ & 714 & \\
\hline
\end{tabular}

${ }^{1} \mathrm{sd}=$ Standard deviation; ${ }^{*} \mathrm{p}=$ value calculated by the chi-square test; ${ }^{* *} \mathrm{p}$ - value calculated by the t-Student test; ${ }^{* *} \mathrm{p}$ - value calculated by Fisher's exact test

When comparing the prevalence of TMD among university students in different programs, no statistically significant difference was found in the proportions. However, a statistically significant difference was observed when analyzing the differences among the means of the ages in relation to the level of TMD severity, with greater severity among older university students. The proportions between the academic terms also presented statistically significant differences, and only the second term presented a greater proportion of university students diagnosed with an absence of TMD. This is unlike the others, who had a greater prevalence of mild TMD.

When comparing the different levels of TMD severity in relation to stress, a statistically significant difference was found between the proportions. Most of the students without stress were diagnosed with absent or mild TMD, while the students with stress presented mild TMD (Table 6). 
Table 6 - Association of the TMD with stress and anxiety among university students of UFJF-GV

\begin{tabular}{|c|c|c|c|c|c|c|}
\hline \multicolumn{5}{|c|}{ TEMPOROMANDIBULARDISORDER(TMD) } & & \multirow[b]{2}{*}{ p-value } \\
\hline & Absence & Mild & Moderate & \multicolumn{2}{|l|}{ Severe } & \\
\hline STRESS & $n(\%)$ & $n(\%)$ & $n(\%)$ & $n(\%)$ & Total & \\
\hline Without stress & $222(33.38 \%)$ & $317(47.67 \%)$ & $107(16.09 \%)$ & $19(2.86 \%)$ & 665 & \multirow{2}{*}{$<0.0001$} \\
\hline With stress & $2(3.57 \%)$ & $18(36.31 \%)$ & $16(33.93 \%)$ & $13(26.19 \%)$ & 49 & \\
\hline \multicolumn{7}{|c|}{ ANXIETY - State } \\
\hline Without anxiety & $18(75.00 \%)$ & $3(12.50 \%)$ & $2(8.33 \%)$ & $1(4.17 \%)$ & 24 & \multirow{4}{*}{$<0.0001$} \\
\hline MILD & $55(49.10 \%)$ & $50(44.64 \%)$ & $6(5.36 \%)$ & $1(0.89 \%)$ & 112 & \\
\hline MODERATE & $64(36.36 \%)$ & $88(50.00 \%)$ & $22(12.50 \%)$ & $2(1.14 \%)$ & 176 & \\
\hline SEVERE & $87(21.64 \%)$ & $194(48.26 \%)$ & $93(23.13 \%)$ & $28(6.97 \%)$ & 402 & \\
\hline \multicolumn{7}{|c|}{ ANXIETY - Trait } \\
\hline Without anxiety & $34(75.56 \%)$ & $10(22.22 \%)$ & $0(0.00 \%)$ & 1(2.22\%) & 45 & \multirow{5}{*}{$<0.0001$} \\
\hline MILD & $59(50.43 \%)$ & $50(42.74 \%)$ & $7(5.98 \%)$ & $1(0.85 \%)$ & 117 & \\
\hline MODERATE & $56(36.13 \%)$ & $76(49.03 \%)$ & $20(12.90 \%)$ & $3(1.94 \%)$ & 155 & \\
\hline SEVERE & $74(18.83 \%)$ & $196(49.87 \%)$ & $96(24.43 \%)$ & $27(6.87 \%)$ & 393 & \\
\hline Not informed & $1(25.00 \%)$ & $3(75.00 \%)$ & $0(0.00 \%)$ & $0(0.00 \%)$ & 4 & \\
\hline
\end{tabular}

Similarly, when comparing the different levels of TMD severity with anxiety, a statistically significant difference among the proportions was observed. Analyzing the relative frequencies in Table 6, it is observed that, in the case of Anxiety-State, among the university students classified as having no anxiety or low anxiety, most of them presented absence of TMD. On the other hand, the university students with moderate or severe anxiety-state presented, for the most part, mild TMD.

For the Anxiety-Trait variable, the proportions showed a statistically significant difference in relation to TMD. Analyzing the relative frequencies in Table 6 , similar to what occurs with Anxiety-State, in the case of Anxiety-Trait the majority of university students classified as having no or low anxiety presented absence of TMD. On the other hand, the majority of university students with moderate or severe anxiety presented mild TMD.

\section{DISCUSSION}

The purpose of the present study was to report the prevalence of different levels of severity of TMD, and the psychological profiles of stress and anxiety, among university students. Based on the data obtained in the present study, the prevalence of mild TMD and moderate anxiety (state and trait) among university students was observed. Due to the diversified results regarding prevalence, regional differences, biological predisposition (which reflects racial differences) and external exposures which may vary as a function of region, the relevance of the of the presented results is substantiated.

The demographic characteristics of the studied population are the result of the prevalence of the female gender, which coincides with other epidemiological studies [13]; those of race may reflect regional characteristics. This is seen in Inglehard et al. [14], in the study with greater prevalence of Americans of African descent. Marital status and mean age 
are characteristics of a young population which composes the daytime programs.

The FAI is used in epidemiological studies for the diagnosis of TMD [15]. The advantages of Fonseca's questionnaire include: simple, selfadministration, short period of administration, low cost, less examiner influence and less variability in the measurements [16]. As the aim of this study was to verify the prevalence of TMD among students during the post-vacation period and without the interference of academic activities that could trigger stress events, the application of FAI, due to its aforementioned characteristics, became viable for the short evaluation period. It was reported that most of the volunteers $(68.63 \%)$ were classified as having TMD. These values are similar to those of other studies, ranging from approximately 40\% to $85 \%[15,17,18]$. In the study by Calixtre et al. [19], a 70.6\% prevalence of TMD was observed in the studied population. Of the volunteers with TMD, $46.92 \%$ were classified with mild TMD, which aligns with studies that obtained similar values $[12,19,20]$. The percentage of volunteers having the disorder was high, and attention should be given to the interpretation of these values since, in order to diagnosis TMD, it is necessary to have the history of the patient associated with a detailed clinical exam and, if necessary, to conduct complementary tests.

In regard to the psychological profiles of the volunteers, the greatest prevalence of stress occurred in the groups of students without stress. This result may be substantiated by the fact that the study was conducted shortly after the recess period, and it was believed that this psychological change would not be present after the vacation period. As for anxiety, both trait as well as state, presented greater prevalence for the severe category. This may be a characteristic peculiar to the population studied or, even, triggered by the expectation of the start of the new academic term with its responsibilities. The psychological profile is variable among the studies, due to the methodology used as well as the moment of data collection $[11,13]$.
Analyzing the association between TMD and the demographic aspects, a statistically significant difference was observed between the proportions of mild TMD and the female gender. These findings agree with other studies that verified the tendency toward TMD among the female gender $[6,12,13,15,20]$. De Oliveira et al. [21], evaluating the prevalence and severity of TMD among university students, also found similar results in that there were significantly more female volunteers classified with mild TMD. In that study, the relationship between the genders was 3:1. The reasons for this are still not completely clear. However, it gives some factors such as physiological characteristics of the gender, muscular structure and lower pain threshold, greater prevalence of psychological disturbances, hormonal variations, as possible explanations for this prevalence [22]. Additionally, the peak for the development of symptoms is between 20 and 40 years, that is, during the reproductive period. This was also observed in the present study, in which the mean age found for the development of TMD was 21.5 years $[13,20]$.

Data obtained for the association of TMD with stress show that there was a statistically significant difference in the proportions between the category without stress and mild TMD. Nevertheless, the presence of stress was greater for mild TMD. Some studies show that persons with TMD present higher levels of stress $[18,23,24]$.

Regarding the association of TMD and anxiety, for both trait and state, there was a statistical difference between severe (trait) and moderate (state) anxiety with mild TMD. Similar data were found in other studies involving the association of anxiety and TMD $[12,18]$. Pesqueira et al. [17] evaluated the relationship between psychological stress and signs of TMD in university students, and revealed an association between anxiety and TMD. However, Azevedo et al. [25] found no association between TMD and anxiety. It is known that psychological states are one of the etiological factors of TMD and exert influence 
as triggering, perpetuating and/or predisposing factors. Anxiety and stress are influenced by external factors such as the demands of the academic term (exams, internships, seminars). This oscillation of psychological factors may contribute to the fluctuating characteristic of TMD.

Finally, some limitations of the present study should be considered. It is a crosssectional study that only allows associations among the variables and, therefore, there are no causal inferences among them (obtained only by longitudinal studies). Additionally, only university students from a public institution were assessed, limiting the extrapolation of the results for university students from private institutions. To diagnose TMD, the literature stresses the importance of a detailed anamnesis associated with clinical exams and, when necessary, complementary tests [1].

\section{CONCLUSION}

According to the data obtained, it may be concluded that there is a high prevalence of TMD signs and symptoms among university students. The greater prevalence was observed for the female gender, and the most significant level of TMD was mild. Regarding the psychological aspect, anxiety was present in a significant number of volunteers diagnosed with TMD. In addition, the presence of TMD was associated with anxiety and stress among university students, in different programs and academic terms.

\section{Disclosure statement}

The authors report no conflicts of interest.

\section{REFERENCES}

1. De Leeuw R. Orofacial Pain: Guidelines for Assessment, Diagnoses and Management. Chicago: Quintessence,2013.

2. Greene CS. Managing the care of patients with temporomandibular disorders: a new guideline for care.J Am Dent Assoc. 2010 Sep;141(9):1086-8.

3. Bevilacqua-Grossi D, Chaves TC, Oliveira AS, Monteiro-Pedro V. Anamnestic index severity and signs and symptoms of TMD. JCraniomandibular Practice. 2006;24:1-7.Cranio. 2006 Apr;24(2):112-8. doi:10.1179/crn.2006.018 ?
4. LeResche L. Epidemiology of temporomandibular disorders: Implications for the investigation of etiologic factors. Crit Rev Oral Biol Med 1997;8:291-305.

5. Adèrn B, Stenvinkel C, Sahlqvist L, Tegelberg Å. Prevalence of temporomandibular dysfunction and pain in adult general practice patients. Acta Odontol Scand. 2014 Nov;72(8):585-90. doi: 10.3109/00016357.2013.878390.

6. Mobilio N, Casettal, CesnikE, Catapano S. Prevalence of self-reported symptoms related to temporomandibular disorders in an Italian population.J Oral Rehabil.2011Dec;38(12):884-90. doi:10.1111/.j1365-2842.2011.02228.x.

7. Gonçalves DA, Dal Fabbro AL, Campos JA, Bigal ME, Speciali JG. Symptoms of temporomandibular disorders in the population: an epidemiological study.J Orofac Pain. 2010;24(3):270-8.

8. Suvinen TI,Hanes KR, Gerscham JA, Reade PC. Psychophisical subtypes of temporomandibular disorders. J Orofac Pain. 1997;11(3):200-5.

9. Vedolin GM, Lobato WV, Conti PCR, Lauris JRP. The impact of stress and anxiety on the pressure pain threshold of myofascial pain patients. J Oral Rehabil. 2009 May;36(5):313-21. doi: 10.1111/j.1365-2842.2008.01932.x.

10. Stallman HM. Psychological distress in university students: a comparison with general population data. Australian Psychologist. 2010;45(4):249-57. doi: 10.1080/00050067.2010.482109

11. Martins RJ, Garcia AR, Garbin CAS, Sundefeld MLMM. Associação entre classe econômica e estresse na corrência da disfunção temporomandibular. Rev Bras Epidem. 2007;10(2):215-22 doi:10.1590/S1415-790X2007000200009.

12. Bezerra BPN, Ribeiro AIAM, Farias ABL, Farias ABL, Fontes LBC, Nascimento SR, Nascimento AS, Adriano MSPF.Prevalência da disfunção temporomandibular e de diferentes níveis de ansiedade em estudantes universitários. Rev Dor.2012; 13(3):235 -242. doi:10.1590/S180600132012000300008 .

13. Wieckiewicz M, Grychowska N, Wojciechowski K, Pelc A, Augustyniak M, Sleboda A, Zietek M. Prevalence and Correlation between TMD Based on RDC/TMD Diagnoses, Oral Parafunctions and Psychoemotional Stress in Polish University Students. Biomed Res Int. 2014;2014:472346. doi: 10.1155/2014/472346.

14. InglehartMR, Patel MH, Widmalm SE, Briskie DM. Self-reported temporomandibular joint disorder symptoms, oral health, and quality of life of children in kindergarten through grade 5:Do sex, race, and socioeconomic background matter? J Am Dent Assoc. 2016 Feb;147(2):131-41. doi: 10.1016/j. adaj.2015.10.001.

15. Karthik R, Hafila MIF, Saravanan C, Vivek N, Priyadarsini P,Ashwath B. Assessing Prevalence of Temporomandibular Disorders among University Students: A Questionnaire Study. J Int Soc Prev Community Dent. 2017 Jun;7(Suppl1):S24-S29. doi:10.4103/jispcd.JISPCD_146_17.

16. Nomura K, Vitti M, Oliveira AS, Chaves TC, Semprini M, Siéssere S, etal. Use of the Fonseca's questionnaire to assess the prevalence and severity of temporomandibular disorders in Brazilian dental undergraduates. Braz Dent J. 2007;18:163-7.

17. Pesqueira AA,Zuim PR, Monteiro DR, Ribeiro PP, Garcia AR. Relationship between psychological factors and symptoms of TMD in university undergraduate students. Acta Odontol Latinoam. 2010;23(3):182-7.

18. Minghelli B,Morgado M, Caro T. Association of temporomandibular disorder symptoms with anxiety and depression in Portuguese college students. J Oral Sci. 2014 Jun;56(2):127-33.

19. Calixtre LB, Grüninger BLS, Chaves TC, Oliveira AB. Is there an association between anxiety / depression and temporomandibular disorders in college students? J Appl Oral Sci. 2014 Jan-Feb;22(1):15-21. doi: 10.1590/1678775720130054 . 
20. Lemos GA, Silva PLP,Paulino MR, Moreira VG, Beltrão RTS, Batista AUD. Prevalência de disfunção temporomandibular e associação com fatores psicológicos em estudantes de Odontologia Rev Cub Estomatol. 2015; 52(4):22-31. Available from:http://www.revestomatologia.sld.cu/index.php/ est/article/view/764/234.

21. de Oliveira AS Dias EM, Contato RG, BerzinF.Prevalence study of signs and symptoms of temporomandibular disorder in Brazilian college students. Braz Oral Res. 2006 Jan-Mar;20(1):3-7. doi:/S1806-83242006000100002

22. Dao TT,LeResche L. Gender differences in pain. J Orofac Pain. 2000;14(3):16984; discussion 184-95.
23. Martins RJ Garbin CAS, Garcia AR, Garbin AJl, Miguel N. Stress levels and quality of sleep in subjects with temporomandibular joint dysfunction. Rev Odonto-ciênc. 2010;25(1):32-6. doi:10.1590/S1980-65232010000100007.

24. Habib SR, AI Rifaiy MQ, Awan KH, Alsaif A, Alshalan A, Altokais Y.Prevalence and severity of temporomandibular disorders among university students in Riyadh. Saudi Dent J. 2015 Jul;27(3):125-30. doi:10.1016/j.sdentj.2014.11.009.

25. Fernandes Azevedo AB, Câmara-Souza MB, Dantas IS, de Resende CMBM, Barbosa GAS. Relationship between anxiety and temporomandibular disorders in dental students. Cranio. 2018 Sep;36(5):300-303. doi: 10.1080/08869634.2017.

\section{Dr Ana Paula Varela Brown Martins}

\section{(Corresponding address)}

Department of Dentistry, Federal University of Juiz de Fora campus

Governador Valadares. Avenida Dr. Raimundo Monteiro Rezende, 330 -

Centro, Governador Valadares/ Minas Gerais, Brazil - CEP 35010-177.

Email: anapaula.martins@ufjf.edu.br

Date submitted: 2019 Jun 19

Accept submission: 2019 Sep 24 